\title{
COVENANTS OF TITLE RUNNING WITH THE LAND IN CALIFORNIA
}

\section{INTRODUCTION}

A person who purchases an estate in land may be taking a gamble. Suppose $A$ sells Blackacre to $B$. If $A$ also sells to $C$, then $B$ and $C$ may have to litigate the ownership of Blackacre. A land buyer may partially protect himself by purchasing title insurance and by making use of the recording offices maintained by the government. A land buyer may also utilize covenants of title, an historical predecessor of both title insurance and the recording acts.

William Henry Rawle, writing in 1887, noted that,

[A]s land became more the subject of transfer, its muniments of title were more readily yielded to the examination of the purchaser, and the latter came to depend rather upon that examination of the title than upon the covenants which were to assure it. This, of course, lessened their practical use .... I

If the recording acts and title insurance adequately protected grantees, there would be no need for covenants of title. There are unrecorded interests, however, against which neither the recording acts nor title insurance offer protection. Even though the instances may be rare in which the grantee is not protected by the recording acts or by title insurance, the grantee's only protection in such a case may be a covenant of title. ${ }^{2}$

The problem becomes acute when the injury occurs to a remote grantee who is relying upon the covenants of title implied by statute. Suppose that $A$ conveys Blackacre to $B$, using the California statutory form of grant deed. Section 1113 of the California Civil Code implies a covenant against prior conveyance; by law $A$ is covenanting that he has not previously conveyed Blackacre. But $B$ now conveys to $C$. In relation to $A, C$ is a "remote grantee." $C$ finds surveyors in his back yard and upon inquiry learns that $A$ had in fact previously conveyed Blackacre to the state highway department for a new freeway. Furthermore, the conveyance to the highway department was of record. $C$, however, had not bothered with a title search. Has $C$ any remedy against $A$ based upon $A$ 's implied covenant against prior conveyance? At the present time, the answer is no. The reasoning that produces this negative answer is the problem of this Comment.

An investigation of covenants that run with the land necessarily involves consideration of several related subjects. First, covenants of title must be isolated from "covenants" in general. Next, it is proper to discuss the various covenants

1 Rawle, Covenants For Title 20 (5th ed. 1887) [hereinafter cited as Rawle]. To an extent, Rawle was right. Express covenants of title seem to be a scarce commodity im contemporary conveyancing of fee interests. However, the covenants of title implied by statute are very much with us. See sections III, A \& C, infra; note 128 infra.

2 Covenants of title probably would be obsolete if all interests in land were recordable. The recording acts would provide adequate protection that would not depend upon the solvency of the grantor. At the present time, however, an interest in land such as one acquired by adverse possession is not recordable and is not covered by the ordinary title insurance policy. Whether it is feasible to make all interests in land recordable is beyond the scope of this Comment. 
of title extant in California, which of these covenants run with the land, and which do not. After setting forth the reasoning presently employed by the courts to determine which covenants run, the reasoning will be analyzed to see whether it justifies the result. As somewhat collateral matters, the recording acts and title insurance are considered briefly in the appendices in order to relate these subjects to covenants of title.

II

COVENANTS OF TITLE

"Covenant" is a broad word. "In common parlance, [a covenant is] any agreement, whether under seal or not."3 A covenant of title is a particular kind of covenant "usually inserted in a conveyance of land, on the part of the grantor, and binding him for the completeness, security, and continuance of the title transferred to the grantee." $A$ A covenant of title is a contractual obligation ${ }^{5}$ with relief for its breach in the form of money damages. ${ }^{6}$

Covenants of title should not be confused with other covenants. Covenants of title are a special kind of covenant and are to be distinguished from the multitude of covenants that may be found in a deed. ${ }^{7}$ Similarly, covenants of title are not conditions, ${ }^{8}$ easements, ${ }^{9}$ or equitable servitudes. ${ }^{10}$ Covenants of title are simply a means of guaranteeing the grantee that he is in fact getting the estate that the grantor purports to convey.

\section{III \\ CAIIFORNIA COVENANTS OF TITLE}

The are six covenants of title in California: (A) of seisin and good title; (B) of the right to convey; (C) against encumbrances; (D) for quiet enjoyment; (E) of further assurance; and (F) of warranty. ${ }^{11}$ Covenants $(A)-(E)$ were Eng-

3 BLACK, LAW Dictionary 436 (4th ed. 1951).

4Id. at 438. There is no difference between a "covenant for title" and a "covenant of title."

5 Barrows v. Jackson, 112 Cal. App. 2d 534, 538-39, 247 P.2d 99, 102 (1952).

6 II AMERICAN Law of Property 363 (Casner ed. 1952). Of course, equitable relief may be granted in a proper case, particularly on a covenant for further assurance. See generally RAwsE ch. 15.

7 Covenants of title are not restrictive covenants or covenants regulating the use of the estate conveyed. If $A$ grants to $B$ and $A$ covenants that he owns the land, it is a covenant of title. When $A$ covenants that he will not block the sun from the land $B$ is taking, however, this is not a covenant of title even though it may be a covenant that runs with the land.

8 "There is a decided distinction between the creation and effect of a condition and a covenant. A condition is a qualification annexed to an estate by the grantor, upon the happening of which the estate granted is enlarged or defeated; and it differs from a covenant in this: That it is created by the mutual agreement of the parties, and is binding upon both, whereas a covenant is an agreement of the covenantor only. A breach of a condition upon which an estate is granted works a forfeiture of the estate, while a breach of a covenant is merely ground for the recovery of damages." Knight v. Black, 19 Cal. App. 518, 522, 126 Pac. 512, 514 (1912).

$\theta$ "An easement is 'an interest in land created by grant or agreement, express or implied, which confers a right upon the owner thereof to some profit, benefit, dominion, or lawful use out of or over the estate of another.' " Huyck v. Andrews, 113 N.Y. $81,85,20$ N.E. 581, 582 (1889), quoted in Los Angeles Terminal Land Co. v. Muir, 136 Cal. 36, 48, 68 Pac. 308, 312 (1902).

${ }^{10}$ A servitude is "'a right which subjects a land or tenement to some service for the use of another land or tenement which belongs to another master." "Los Angeles Terminal Land Co. v. Muir, $136 \mathrm{Cal}$. 36, 48, $68 \mathrm{Pac}$. 308, 312 (1902). A court will enjoin the violation of a covenant restricting the free use of land against an assignee taking with notice, even if the covenant is personal. Wayt v. Patee, 205 Cal. 46, 49, 269 Pac. 660, 662 (1928).

11 The covenant of warranty is a specific covenant of title and is not to be confused with a "warranty." A grantor may "warrant against encumbrances," but this is a covenant against encumbrances. 
lish common-law covenants; the covenant of warranty (F) seems to be an American invention. ${ }^{12}$ The first three covenants do not run with the land; ${ }^{13}$ the last three do. ${ }^{14}$

This section describes the California covenants of title. The analysis of these covenants is reserved for section IV infra.

\section{A. The Covenant of Seisin and Good Title}

The covenant of seisin is a covenant that the grantor is the owner of the property conveyed..$^{15}$ Early cases in this country held that the covenant of seisin was broken, if at all, when made, ${ }^{16}$ and thereupon became a chose in action. It could not run with the land because a chose in action could not be assigned. ${ }^{17}$ With practically no discussion, the California court adopted the same rule in Lawrence $v$. Montgomery. ${ }^{18}$ Even though a chose in action may now be assigned, ${ }^{18}$ a remote grantee has no remedy based on the original grantor's covenant of seisin in the absence of an express assignment of the chose in action. ${ }^{20}$

In addition California implies a covenant that appears to be a statutory modification of the covenant of seisin, though much narrower in scope than the commonlaw covenant. California Civil Code section 1113 reads in part:

From the use of the word "grant" in any conveyance by which an estate of inheritance or fee simple is to be passed, the following covenants ... are implied ... T. That

12 See Rawle 17.

13 "The terms 'real covenants' or 'covenants running with the land' are, of course, metaphorical. The covenants are always personal in the sense that they are enforced in personal actions for damages, etc.; and they cannot actually run with the land .... [T] merely how far the transfer of an interest in land will also transfer either the benefit or the burden of covenants concerning it." CLARK, REAL CovenaNts 93 n.3 (2d ed. 1947) [hereinafter cited as CLARE].

14 These covenants are specified in CAL. Crv. CODE \& 1463, which reads in part: "The last section [\$ 1462 infra] includes covenants 'of warranty,' 'for quiet enjoyment,' or for further assurance on the part of a grantor ...."

CaI. Crv. CODE § 1462 reads: "Every covenant contained in a grant of an estate in real property, which is made for the direct benefit of the property, or some part of it then in existence, runs with the land."

15 See McCormick v. Marcy, 165 Cal. 386, 388, 132 Pac. 449, 450 (1913). Rawle defined a covenant of seisin as " an assurance to the purchaser that the grantor las the very estate in quantity and quality which he purports to convey.' [Howell v. Richards, 11 East 633, 103 Eng. Rep. 1150 (K.B. 1809) per Lord Ellenborough.]" RAwLE 72.

${ }_{16}$ The covenant is not broken at all unless the technical seisin of the purchaser is affected. See RAWLE 74.

17 Thayer v. Clemence, 39 Mass. (22 Pick.) 490, 494 (1839) ; Greenby v. Wilcocks, 2 Johns. R. 1, 4 (N.Y.Sup. Ct. 1806) ; Hanilton v. Wilson, 4 Johns. R. 72 (N.Y.Sup. Ct. 1809).

$1837 \mathrm{Cal} .183$ (1869). The case came up on demurrer and it was held that there was an improper joinder of parties plaintiff because the complaint did not allege an assignment of the chose in action. Nevertheless, the case quoted with approbation a statement by Kent that choses in action are technically not assignable. Id. at 188-89. In Salmon v. Vallejo, the court cited Lawrence and said: "A covenant of seisin, or that the grantor has lawful right to convey, or that the land is free from incumbrances, is a personal covenant, and when broken is broken as soon as made. The right of action upon it is a mere chose in action, and docs not run with the land." 41 Cal. 481,484 (1871). This is so even though the grantor does not know that there is an encumbrance at the time of conveyance. Ibid. See also McCornick v. Marcy, $165 \mathrm{Cal}$. 386, 388, 132 Pac. 449, 450 (1913) (covenant broken when made).

19 Cal. Crv. Code $\S 954$.

20 If the grantee can recover, the measure of damages is determined by Cax. Crv. Code $\$ 3304$. 
previous to the time of the execution of such conveyance, the grantor has not conveyed the same estate, or any right, title or interest therein, to any person other than the grantee....

This is a special covenant of seisin; the grantor is covenanting that he himself has not previously conveyed the estate. This covenant also is broken when made ${ }^{21}$ and does not run with the land. ${ }^{22}$

\section{B. The Covenant of the Right to Convey}

The covenant that the grantor has the right to convey the property is much the same as the covenant of seisin. It can be used, however, where the grantor does not own the property, but still has the right to convey it. ${ }^{23}$

Early cases in this country held that the covenant of right to convey was broken when made, and once broken became a chose in action that was not assignable. ${ }^{24}$ California followed suit. ${ }^{25}$

\section{The Covenant Against Encumbrances}

" $[E]$ very right to, or interest in, the land granted, to the diminution of the value of the land, but consistent with the passing of the fee of it by the convey. ance, must be deemed in law an incumbrance." ${ }^{26}$ California courts, ${ }^{27}$ following early American cases, ${ }^{28}$ held that the covenant against encumbrances was broken when inade, since the encumbrance existed when the deed was made. The covenaut does not run with the land. ${ }^{29}$

California Civil Code section 1113 implies a special covenant against encumbrances when the word "grant" is used in a deed.$^{30}$ By the statutory covenant

21 Lawrence v. Montgomery, 37 Cal. 183, 188 (1869). The statute interpreted in Lawrence was substantially the same as the present CAL. Crv. CoDE $\S 1113$. Undoubtedly Lawrente is good authority for a similar interpretation of $\S 1113$. See, e.g., McPike v. Heaton, $131 \mathrm{Cal}$. 109, 63 Pac. 179 (1900).

22 Lawrence v. Montgomery, 37 Cal. 183, 188 (1869). See McPike v. Heaton, 131 Cal. 109, 63 Pac. 179 (1900).

23 For example, a grantor might be able to sell the property without owning it if he were an agent making the sale on behalf of his principal. The covenant of right to convey was used in England when the practice was to convey to the use of another party. See RAwLE 82.

24 See, e.g., Bickford v. Page, 2 Mass. 455 (1807).

25 Salmon v. Vallejo, 41 Cal. 481 (1871); Lawrence v. Montgomery, 37 Cal. 183 (1869). 26 Prescott v. Trueman, 4 Mass. 627,629 (1808).

27 McPike v. Heaton, 131 Cal. 109, 63 Pac. 179 (1900) ; Woodward v. Brown, 119 Cal. 283, 294, 51 Pac. 2, 5,51 Pac. 542 (1897); Salmon v. Vallejo, 41 Cal. 481 (1871); Lawrence v. Montgomery, 37 Cal. 183, 188-89 (1869); Wright v. Boggess, 24 Cal. App. 533, 535-36, 141 Pac. 1082 (1914).

28 See, e.g., Clark v. Swift, 44 Mass. (3 Met.) 390 (1841); Thayer v. Clemence, 39 Mass. (22 Pick.) 490, 494 (1839); Prescott v. Trueman, 4 Mass. 627, 629 (1808).

29 See cases cited in note 27 supra.

39 Cax. Civ. CODE $§ 1113$ reads:

Froin the use of the word "grant" in any conveyance by which an estate of inheritance or fee simple is to be passed, the following covenants, and none other, on the part of the grantor for himself and his heirs to the grantee, his heirs, and assigns, are imphed, unless restrained by express terms contained in such conveyance:

1. That previous to the time of the execution of such conveyance, the grantor has not conveyed the same estate, or any right, title, or interest thercin, to any person other than the grantee;

2. That sueh estate is at the time of the execution of such conveyance free from encumbrance done, made, or suffered by the grantor, or any person claiming under him.

Such covenants may be sued upon in the same manner as if they had been expressly inserted in the conveyance. 
against encumbrances, the grantor covenants only that he himself has not encumbered the land. Furthermore, the covenant is implied only when an estate of inheritance or fee simple is conveyed, ${ }^{31}$ and not when the conveyance purports to pass only right, title, and interest (a quitclaim deed).$^{32}$ If a sale is made subject to a certain encumbrance, it is implied under the statute that the title is free from any other encumbrances. ${ }^{33}$ The statutory covenant does not apply when there is a devise or gift, since there is no consideration for the covenant. ${ }^{34}$

A covenant against encumbrances is a covenant to indemnify the grantee. ${ }^{35}$ Until the grantee has sustained a loss, he is entitled to no recovery..$^{36}$ Even though the loss may not become apparent for some years, the statute of limitations runs from the time of conveyance. ${ }^{37}$

\section{The Covenant for Quiet Enjoyment}

A covenant for quiet enjoyment is a promise that the grantee will not be disturbed because of a defective title. ${ }^{38}$ The covenant is broken whenever there is an eviction, constructive or actual, by a paramount title. ${ }^{39}$ Eviction by a mere trespasser does not breach the covenant. ${ }^{40}$ California Civil Code section 1463 provides that the covenant for quiet enjoyment runs with the land..1 Undoubtedly, it would run if there were no statute..$^{42}$

The covenant of quiet enjoyment is very similar to the covenant of warranty, considered below. It should be noted that a covenant for quiet enjoyment can accomplish virtually the same things as the covenants of seisin or right to convey. If the grantor does not own the land and the grantee is evicted, then the covenant of quiet enjoyment has been breached.

\section{E. The Covenant for Further Assurance}

A covenant for further assurance is "an undertaking on the part of the vendor to do sucl further acts for the purpose of perfecting the purchaser's title as the latter may reasonably require ...."43 It "is substantially a covenant that the vendor will . . . perform all 'acts, deeds, conveyances and assurances' . . . which

31 Southern Pacific Co. v. Dore, 34 Cal. App. 521, 523, 168 Pac. 147 (1917).

32 Ibid. In California, the words "grants right, title, and interest" are held to be a quitclaim. Id. at 522, $168 \mathrm{Pac}$. at 147 .

${ }_{33}$ Mains v. City Title Ins. Co., 34 Cal.2d 580, 585, 212 P.2d 873, 876 (1949); Smiddy v. Grafton, 163 Cal. 16, 18, 124 Pac. 433, 434 (1912).

34 Estate of Porter, 138 Cal. 618, 624, 72 Pac. 173, 175 (1903).

35 Wright v. Boggess, 24 Cal. App. 533, 535-36, 141 Pac. 1082 (1914). The measure of damages is determined by CAI. Crv. CODE $\S 3305$.

38 Wright v. Boggess, 24 Cal. App. 533, 535-36, 141 Pac. 1082 (1914).

37 Some jurisdictions have divided encumbrances into "physical" encumbrances and "money" encumbrances. This solution is considered in more detail in section $T, E$ infra.

38 See Rawle 119.

${ }^{39}$ See McGary v. Hastings, 39 Cal. 360, 366-67 (1870). "There is no breach of the covenant for quiet and peaceable possession of land until there has been an eviction by the true owner, or an assertion by him of his paramount right in such a manner that the holder through the covenantor is compelled to yield possession or buy the outstanding superior title." McCormick v. Marcy, 165 Cal. 386, 389, 132 Pac. 449, 450 (1913).

40 Playter v. Cunningham, $21 \mathrm{Cal} .229,233$ (1862).

41 See note 14 supra.

42 See Soderberg w. Holt, 86 Utah 485, 46 P.2d 428 (1935). The covenant would run because it is a future covenant. The problem of present and future covenants is considired in section IV, B infra.

43 RawLE 130. 
may be wanting to the confirmation of the vendee's title."14 A covenant for further assurance will carry with it a covenant against encumbrances, ${ }^{45}$ but when placed in a quitclaim deed will not pass after-acquired title. ${ }^{46}$ Upon a proper showing, a court will grant specific performance of a covenant for further assurance, ${ }^{47}$ though precisely what the covenant covers depends somewhat upon the fact situation. ${ }^{48}$ The covenant runs with the land in California. ${ }^{40}$

\section{F. The Covenant of Warranty}

By a covenant of warranty, the covenantor promises that he will compensate the covenantee if the title to any part of the estate fails because a third party asserts a superior title. ${ }^{50}$

A covenant of warranty is not broken until there is an eviction, constructive or actual, under paramount title. ${ }^{51}$ The covenant runs with the land. ${ }^{52}$

A covenant of warranty in a quitclaim deed will not estop the grantor from setting up an after-acquired title, ${ }^{53}$ because the covenant applies only to the interest conveyed ${ }^{54}$ A covenant of warranty and a covenant of "non-claim" are the same thing. ${ }^{55}$

\section{IV}

\section{COVENANTS OF TITLE THAT RUN WITH THE LAND}

Covenants for title have a confused history. They originated in England at a time when contracts were not assignable. ${ }^{56}$ It was felt, however, that the assignees

44 Armstrong v. Darby, 26 Mo. 517, 520 (1858).

45 Clarke v. Priest, 21 App. Div. 174, 179, 47 N.Y. Supp. 489, 493 (1897). Contra, Baudendistel v. Zabriskie's Exrs., 50 N.J. Eq. 453, 456, 26 Atl. 455, 456 (1892).

48 Whaley v. Cavanaugh, $88 \mathrm{Cal} .132,135,25 \mathrm{Pac} .1112,1113$ (1891) (dictum).

47 See Baudendistel v. Zabriskie's Exrs., 50 N.J. Eq. 453, 26 AtI. 455 (1892).

48 Zabriskie v. Baudendistel, 20 Atl. 163, 165-66 (N.J. Ch. 1890), aff'd, 50 N.J. Eq. 453, 26 Atl. 455 (1892):

The covenant for further assurance will, it is true, always be considered in connection with the other covenants in the deed, and with the estate granted by the deed, in order to determine whether it was the intention of the parties that the covenant sbould extend to the act demanded .... "The covenant for further assurance in a deed is a covenant intended to give full effect and operation to the estate and interest conveyed by the deed." . . An essential difference between the covenant for furtber assurance and the covenant of quiet enjoyment and warranty is that, on breach of the latter, the validity of the adverse claim must be determined by proceedings taken by the adverse claimant against the grantee, or by what is equivalent thereto, wbile, on a bill for specific performance of the covenant for further assurance, the validity of the claim is determined in a suit between the grantee and grantor, to which the clainant is not a party, and by which he is not bound.

49 See note 14 supra. The covenant for further assurance could probably be excluded from the list of California covenants of title but for its mention in CaL. Crv. CODE $\$ 1463$. There would seem to be little need for the covenant, since the covenant of warranty is much the same. See section III, F infra. Furthermore, Cat. Crv. CoDE $\$ 1106$ covers the problem of afteracquired title.

50 King v. Kerr's Adm'rs, 5 Ohio 155, quoted in Tropico Land \& Improvement Co. v. Lambourn, 170 Cal. 33, 38, 148 Pac. 206, 208 (1915).

51 See Annot., 50 A.L.R. 180, 185 (1927). See Blackwell v. Atkinson, 14 Cal. 470 (1859).

52 See note 14 supra. See Blackwell v. Atkinson, 14 Cal. 470 (1859).

53 Barrett v. Birge, 50 Cal. 655, 659 (1875); Kimball v. Semple, 25 Cal. 441, 452 (1864).

54 Emeric v. Alvarado, 90 Cal. 444, 459, 27 Pac. 356, 361 (1891); Barrett v. Birge, 50 Cal. 655,659 (1875); Kimball v. Semple, 25 Cal. 441, 452 (1864).

65 Gee v. Moore, 14 Cal. 472 (1869). See also Morrison v. Wilson, 30 Cal. 344, 348 (1866).

56 II American Law of Property 335-36 (Casner ed. 1952). 
of the covenantor and of the covenantee should be subject to the duties and entitled to the rights of the contract. ${ }^{57}$ To accomplish this, the courts treated the contract as if it were attached to the estate ${ }^{58}$ or as if it were something like an interest in land. ${ }^{68}$

Though covenants of title remain shrouded by the cloak of history, certain requirements have evolved that must be met for any covenant, including a covenant of title, to run with the land. ${ }^{60}$

\section{A. The Problem of Privity}

\section{Privity of Contract and Privity of Estate}

Covenants of title were developed to fill a need in English law-the need to protect remote grantees when contracts were not assignable. For the courts in good conscience to permit the remote grantee to sue the original grantor for breach of the covenant, some connection between the parties was necessary. This connection was provided by privity. There could be privity of contract or privity of estate.

There is privity of contract between the original parties to the agreement. ${ }^{61}$ Parties in privity of contract are bound by their covenants, ${ }^{62}$ whether or not the covenant runs with the land. ${ }^{63}$ If the immediate grantee were to include an express assignment of the benefit of his covenants of title in his conveyance to the remote grantee, ${ }^{64}$ then it would be immaterial whether the covenant ran with the land. The necessary relationship between the grantor and the remote grantee would be provided, and the remote grantee could sue as if he were an original party to the contract. ${ }^{65}$

Privity of estate is more comphicated. It was developed to permit enforcement of covenants when there was no remedy in contract. It was merely a theory that served to place the remote grantee in a legal relationship with the grantor. ${ }^{86}$

No one seems certain what privity of estate is. Clark feels that the cases provide three different definitions:

1. Privity of estate is "succession to the estate of one of the parties to the

57 Ibid. Both benefit and burden ran with the lessee's estate after Quia Emptores, $18 \mathrm{Edw}$. I, cc. 1,3 (1290); and both benefit and burden ran with the reversion as well after the statute of 32 Henry VIII, c. 34 (1540). Id. at 337.

58 II Amarican Law of Property 335-36 (Casner ed. 1952).

50 For an extraordinarily long and equally dull discussion of covenants of title and their history, see RAWLE.

${ }^{80}$ See generally Cax. Crv. Code $\$ \S 1457-70$.

61 See 1, 4 Corbin, Contracts $\$ \S 124,778$ (1950). In California, "privity of contract" probably includes the assignees of the original parties to the agreement. See Werner v. Graham, 181 Cal. 174, 179, 183 Pac. 945, 947 (1919) (dictum).

62 Barrows v. Jackson, 112 Cal. App. 2d 534, 538, 247 P.2d 99, 102 (1952).

03 Ibid. Accord, Pratt-Low Preserving Co. v. Evans, 55 Cal. App. 724, 728-29, 204 Pac. 241, 243 (1921). See Coburn v. Goodall, 72 Cal. 498, 503-04, 14 Pac. 190, 193-94 (1887).

84 "Benefits" of contracts may be assigned in California. Cax. CIv. CoDE § 1458. Whether covenants of title are benefits is discussed in section IV, A, 2 infra. This does not mean that the benefits of covenants imphed under CAI. Crv. CoDE $\$ 1113$ could be assigned as covenants; they could be assigned as choses in action, however, for reasons that will be investigated in section IV, D infra.

65 Whetber or not there is privity of contract in this situation is purely a semantic problem, depending on what one chooses to call "privity of contract." See note 61 supra. No matter what it is called, there is a remedy on the contract. See note 64 supra.

${ }^{66}$ See generally CLARK 92-143. 
covenant ...."67 By this definition, if $A$ and $X$ were parties to a covenant, and if $A$ conveyed to $B$ and $X$ to $Y$, then $B$ and $Y$ would be in privity of estate.

2. Privity of estate is "succession of estate also between covenantor and coveantee, an entirely unjustifiable meaning . ...."68

3. Privity of estate is "mutual and simultaneous interests of the parties in the same land ...." ${ }^{\prime 89} \mathrm{By}$ this defimition, tenants in common would be in privity of estate. Similarly, it would seem, a grantor and a grantee would be in privity of estate if the grantor retained a reversion.

California Civil Code section 1465 seems to provide one definition of privity of estate. It reads: "A covenant running with the land binds those only who acquire the whole estate of the covenantor in some part of the property." This is similar to Clark's first definition, but three things should be noted about the code section. First, it refers to "binds"; the definition applies only to burdensome covenants. Second, the defimition applies only to those "who acquire the whole estate of the covenantor."'70 In a covenant of title, the grantor is always the covenantor. Third, the defintion requires the "whole estate" to be conveyed. The "whole estate" has been defined to be the whole interest in the land, ${ }^{71}$ which means that there can be no privity of estate if the grantor retains a reversion.

Nevertheless, some California cases state that there can be no privity of estate unless the grantor retains a reversionary interest. ${ }^{72}$ This would seem to fall within Clark's third definition. Obviously there is some confusion in California as to what privity of estate is.

Since both Cahfornia Civil Code section $1465^{\circ}$ and the cases requiring a reversionary interest deal with burdens, however, it is possible that the whole problem can be avoided if covenants of title are benefits. The question thus becomes whether covenants of title are benefits rather than burdens, and whether privity of estate is essential for benefits to run in California.

G7 CIARK 111.

68 Ibid.

69 Ibid.

70 Emphasis added.

71 See Backus v. Duffy, 103 Cal. App. 775, 284 Pac. 954 (1930).

72 Bresee v. Dunn, 178 Cal. 96, 100, 172 Pac. 387, 389 (1918); Berryman v. Hotel Savoy Co., 160 Cal. 559, 565, 117 Pac. 677, 679 (1911); Los Angeles Terminal Land Co. v. Muir, $136 \mathrm{Cal} .36,41,68 \mathrm{Pac}$. 308, 309 (1902). These cases were concerned with the requirement of privity of estate for a burden to run. The cases are subject to criticism because they permitted a burden to run without satisfying the requirements of CAI. Crv. CoDE $\$ 1468$, although the holdings may be justifiable on other grounds.

CAL.'Crv. CODE $\$ 1461$ reads: "The only covenants which run with the land are those specified in this title, and those which are incidental thereto." Covenants in a deed for the direct benefit of the land run because of Car. Crv. CoDE $\$ 1462$. Covenants for the addition of some new thing to the property run only if the covenantor binds bis assigns. CAr. Crv. CoDE $\$ 1464$. CAr. Civ. Code $\$ 1468$ would seem to be the only section under which a burden can be made to run with the land, as far as a fee interest is concerned. (Car. Crv. CoDE $\$ \S 1469,1470$, deal with leasehold interests.) Section 1468 apphes only to covenants inade between owners of land; covenants contained in a grant of real property are governed solely by CAL. Crv. CoDE $\$ 1462$. Marra v. Aetna Construction Co., 15 Cal.2d 375, 377, 101 P.2d 490, 492 (1940). It would seem that a burdensome covenant can never run with the land if the burdensome covenant is contained in the deed. A possible exception is $\$ 1464$ deahing with things not in being. Of course, with many covenants a court might find an equitable servitude, see section II supra, but the point remains that if covenants of title are burdens they should never be able to run with the land. In theory it is possible that two different owners of land would enter into covenants of title, but this circumstance seems unlikely; generally speaking, covenants of title are found in the deed. 


\section{Benefits and Burdens}

"The individual who has the right, privilege, or power ... has the benefit; the one who has the duty, no-right, or liability has the burden." sections distinguish between benefit and burden in transferring obligations, ${ }^{74}$ and the same distinction is generally made in covenants relating to real property. ${ }^{75}$

For a covenant to run with the land and enable the remote grantee to sue the original grantor in the event of a breach, the covenant must relate to the land. In England, the covenant would not run if it did not "touch and concern" the land.78 Similarly, in California for a covenant in a deed to run it must directly benefit the land conveyed.77

Benefits run because of California Civil Code section 1462, which states: "Every covenant contained in a grant of an estate in real property, which is made for the direct benefit of the property, or some part of it then in existence, runs with the land." If a covenant of title is a "direct benefit," it should run with the land.

In order to benefit the land directly, the covenant need not relate to a physical benefit such as indoor plumbing. It is enough that the agreement in some way benefits the title or any interest therein ${ }^{78}$ or directly benefits the estate or interest of the covenantee. ${ }^{79}$ Covenants of title are for the protection of the grantee's estate, and the grantee is the covenantee. It follows that covenants of title are "benefits" and should run with the land under California Civil Code section 1462.

The conclusion that covenants of title are benefits is supported by another factor. To an extent, the legislature defined "direct benefit" in California Civil Code section 1463 by naming three covenants of title. ${ }^{80} \mathrm{It}$ would seem that a covenant of seisin benefits the land to the same extent as a covenant for quiet enjoyment, and that all covenants of title beriefit the land equally, as far as section 1462 is concerned. If three covenants of title are "direct benefits" under California Civil Code section 1462, there would seem to be no reason why all covenants of title should not be so classified. ${ }^{81}$

73 CLARK 4.

74 CAL. CIv. CoDE $\$ 1457$ reads: "The burden of an obligation may be transferred with the consent of the party entitled to its benefit, but not otherwise, except as provided by section fourteen hundred and sixty-six."

CAL. Crv. CoDE $\S 1458$ reads: "A right arising out of an obligation is the property of the person to whom it is due, and may be transferred as such."

75 See Annot., 68 A.L.R.2d 1022, 1024 (1959).

76 Spencer's Case, 5 Co. Rep. 16A, 77 Eng. Rep. 72 (K.B. 1583).

77 CAL. Crv. CoDE $\$ 1462$. Only those covenants for the benefit of the property and contained in the grant run with the land; the parties may not make a covenant run by mere wording to that effect in a separate contract. California Packing Corp. v. Grove, 51 Cal. App. 253, 255, 196 Pac. 891, 892 (1921).

$78 \mathrm{~A}$ covenant is made for the direct benefit of the property if it is one "which concerns the land itself, or in any manner or measure affects its title or any interest therein . . ." Carlson v. Lindauer, 119 Cal. App. 2d 292, 305, 259 P.2d 925, 931 (1953).

79 "A covenant in a mortgage providing for the removal of the lien of the mortgage from certain specified portions of the land mortgaged is a covenant for the unfettering, pro tanto, of the title, and is, therefore, for the direct benefit of the land." Sacramento Suburban Fruit Lands Co. v. Whaley, 50 Cal. App. 125, 130, 194 Pac. 1054, 1056 (1920).

80 See note 14 supra.

81 "Unless, however, the covenant come clearly within the description of those specifically mentioned in section 1463, the general test determinative of the question whether a certain covenant runs with the land would seem to be whether it is for the direct benefit of the land." Sacramento Suburban Fruit Lands Co. v. Whaley, 50 Cal. App. 125, 130, 194 Pac .1054, 1056 (1920). 
A covenant intended to benefit the land is incident to the land, and runs with it; whoever becomes the owner of the land is entitled to the benefit of the covenant. ${ }^{82}$ It would follow that privity of estate is not required for a benefit to run with the land in California. ${ }^{83}$ Since covenants of title are benefits, they should all run with the land whether or not there is privity of estate. ${ }^{84}$ This is not the case. ${ }^{85}$ There is a further distinction that determines which run and which do not, even though all covenants of title should be classified as benefits.

\section{B. Covenants In Praesenti and In Futuro}

There are two kinds of covenants of title, in futuro (future) covenants and in praesenti (present) covenants. ${ }^{86}$ Those covenants that run with the land are future covenants, while those that do not run with the land are present covenants. ${ }^{87}$ The distinction rests upon the times at which the covenants are broken.

A present covenant is broken when made, but a future covenant is not broken until there is an act that constitutes a breach. ${ }^{88}$ If $A$ conveys to $B$, and $A$ covenants that he owns the land when in fact lie does not, the covenant has been broken at that moment. ${ }^{89}$ However, if $A$ conveys to $B$, and $A$ covenants that he will warrant

82 Carlson v. Lindauer, 119 Cal. App. 2d 292, 305, 259 P.2d 925, 932 (1953). Accord, Los Angeles Terminal Land Co. v. Muir, 136 Cal. 36, 41, 68 Pac. 308, 309 (1902). Contra, Werner v. Graham, 181 Cal. 174, 180, 183 Pac. 945, 947 (1919) (dictum). Of course, covenants can not literally "run with the land"; someone has to carry them. "[T] he question is merely how far the transfer of an interest in land will also transfer either the benefit or the burden of covenants concerning it." CLARK 93 n.3. That neither party may have land with which the covenant could run suggests that the words "run with the land" are to be considered as an expression rather than as a literal definition.

${ }^{83}$ This conclusion is the same for either of the two definitions of privity of estate in Cahfornia, since both of those definitions deal only with burdens.

An interesting quotation from Clark may be a source of confusion. "A question has arisen whether privity of estate is necessary in order that the benefit may run, it being argued that the benefit is not an encumbrance and should run anyway. . . . But it is obvious that privity in the first sense [see text at note 67 supra] is necessary in order to secure the transfer of the covenant, which is not to be treated as an easement." CLARK 131-32. Unfortunately, this is not all that obvious. The covenant is transferred in California hecause it is a benefit and is considered as incident to the land. CAL. CIv. CODE $\$ 1462$; see cases cited in note 82 supra. Even though a covenant is not an interest in land, California may be treating it as something very unucb akin thereto. Whatever the theoretical complication, the practical result is that when dealing with covenants that benefit, one may look to the "direct benefit" test of $\$ 1462$ without worrying about the ambiguous concept of privity of estate.

84 The discussion of covenants that benefit the land pertains only to the grantce's interest. The grantor is the one who is burdened, and bis obhigation remains personal unless assumed by another. The remote grantee would be able to sue only the covenanting grantor or those legally hable for his obligation. See Los Angeles Terminal Land Co. v. Muir, 136 Cal. 36, 41, 68 Pac. 308, 310 (1902).

85 See section III supra for a listing of the covenants that run.

86 Actually, the two kinds of covenants are real covenants and personal covenants or "covenants in gross." To avoid semantic confusion, these words are avoided in the text. In futuro and in praesenti explain why covenants are "real" or "personal." If a covenant of title is future (in futuro), then it is a real covenant and runs with the land. If a covenant of title is present (in praesenti), then it is personal and does not run with the land.

87 Most of the cases use the Latin forms, but this seems an unnecessary complication.

${ }^{88}$ See generally Greenby v. Wilcocks, 2 Johns. R. 1 (N.Y. Sup. Ct. 1806); Soderberg v. Holt, 86 Utah 485, 489, 46 P.2d 428, 429 (1935).

89 Thayer v. Clemence, 39 Mass. (22 Pick.) 490, 494 (1839). Accord, Lawrence v. Montgomery, $37 \mathrm{Cal}$. 183, 188-89 (1869). 
and defend $B$ 's title (the covenant of warranty), the covenant is not broken until $B$ calls upon $A$ to defend the title and $A$ does not do so..$^{90}$ This is a future covenant.

A present covenant becomes a chose in action when broken and no covenant remains to benefit the land. ${ }^{91}$ Consequently a present covenant is a personal agreement between grantor and grantee that cannot run with the land ${ }^{92} \mathrm{~A}$ future covenant, on the other hand, remains intact until some future breach. Thus there is a continuing promise that benefits the land and runs with it.

California Civil Code section $1462,{ }^{93}$ permitting covenants that benefit the land to run therewith, has no application to a present covenant. From the moment of conveyance there is not a covenant but rather a chose in action, and section 1462 does not say that a chose in action is assigned by operation of deed. Admittedly the only practical difference between having a covenant run with the land and liaving a chose in action assigned automatically by the conveyance is that the statute of limitations starts runming at a different time. Because of this somewhat technical difference, however, section 1462 does not apply to present covenants. ${ }^{94}$

The covenants of seisin, ${ }^{95}$ right to convey, ${ }^{96}$ and against encumbrances ${ }^{97}$ are broken when made. From the instant of the conveyance, the covenants are choses in action. There is no promise to benefit the land; the covenants-or more properly, the choses in action-do not run with the land. ${ }^{98}$ The covenant against encumbrances presents a special problem, and is considered in more detail below.

The covenants of quiet enjoyment, for further assurance, and of warranty are broken when an event arises in the future that occasions a breach. Since these

\footnotetext{
90 Ibid.

91 Greenby v. Wilcocks, 2 Jobns. R. 1, 4 (N.Y. Sup. Ct. 1806).

02 The reasons are largely historical.
}

Choses in action are incapable of assignment, at the common law; and what can distinguish these covenants, broken the instant they are made, from an ordinary chose in action? ... The covenants, it is true, are such as run with the land, but here the substratum fails, for there was no land, whereof the defendant was seised, and of consequence, none that he could aliere; the covenants are, therefore, naked ones, uncoupled with a right to the soil. This point was determined in the case of Lewis v. Ridge. (Cro. Eliz. 863.) The court held, in that case, that the covenant being broken before the plaintiff's purchase, and so, though the covenants were against the precise incumbrance, that it was a thing in action, which could not be transferred over, and judgment was given for the defendant on demurrer. I cannot find that this case has been overruled.

Greenby v. Wilcocks, 2 Johns. R. 1, 4 (N.Y.Sup. Ct. 1806).

Even though choses in action now may be assigned in California, the essential reasoning has remained-there is a chose in action, not a covenant at all, in the case of present covenants. Though the reasoning may be academically sound, the result seems undesirable. The remote grantee is not being protected.

83 CAx. CIv. CODE $\$ 1462$ reads: "Every covenant contained in a grant of an estate in real property, which is made for the direct benefit of the property, or some part of it then in existence, runs with the land."

04 See McPike v. Heaton, 131 Cal. 109, 63 Pac. 179 (1900) ; Salmon v. Vallejo, 41 Cal. 481 (1871) ; Lawrence v. Montgomery, 37 Cal. 183 (1869).

95 McCormick v. Marcy, 165 Cal. 386, 388, 132 Pac. 449, 450 (1913) ; Salmon v. Vallejo,

41 Cal. 481 (1871); Lawrence v. Montgomery, 37 Cal. 183 (1869).

96 Cases cited in note 95 supra.

07 McPike v. Heaton, 131 Cal. 109, 63 Pac. 179 (1900); Woodward v. Brown, 119 Cal. 283, 294, 51 Pac. 2, 5, modified per curiam, 51 Pac. 542 (1897); Salmon v. Vallejo, 41 Cal. 481 (1871) ; Lawrence v. Montgomery, 37 Cal. 183, 188-89 (1869); Wright v. Boggess, 24 Cal. App. 533, 535-36, 141 Pac. 1082 (1914).

08 Salmon v. Vallejo, 41 Cal. 481 (1871); Lawrence v. Montgomery, 37 Cal. 183 (1869). 
covenants are not converted into choses in action until this event, they are future covenants $^{98}$ and run with the land. ${ }^{100}$

\section{The Purpose of Covenants of Title}

The distinction between present and future covenants explains why some covenants run while others do not. Even though the logic is impeccable, the result is subject to criticism. In the absence of an express assignment, the remote grantee has no remedy against the original grantor for the breach of a present covenant. ${ }^{101}$ Suppose $A$ sells to $B$, using a statutory form of grant deed that implies special covenants of seisin and against encumbrances. ${ }^{102}$ Both of these are present covenants. ${ }^{103} B$ conveys to $C$, again using the statutory form of grant deed. $B$, however, is covenanting only that he himself did not previously convey and did not previously encumber the land. ${ }^{104}$ Assuming that $A$ had encumbered the land, $C$ has no remedy against $A$ or $B$. $B$ has not covenanted against $A$ 's acts, and $C$ has no remedy on the basis of $A$ 's present covenants. If the covenants ran with the land, however, $C$ would have a remedy.

Since the contract measure of damages is always used, covenants of title are really to indemnify the grantee for any loss he sustains. ${ }^{105}$ In Soderberg v. Holt, ${ }^{100}$ it was concluded that covenants against encumbrances are covenants to indemnify, when the encumbrance is a charge or lien that can be extinguished by payment. To arrive at this conclusion, the court discussed the "true intention" of the covenant against encumbrances, and said that the covenant against encumbrances "should be looked at as a covenant to indemnify." 107 The Soderberg. court was

98 See Soderberg v. Holt, 86 Utah 485, 46 P.2d 422 (1935).

100 See CaL. CIv. Code $\S 1463$. There is no reason to suspect that these covenants would not run with the land if $\S 1463$ had never been enacted. In Lawrence v. Montgomery, $37 \mathrm{Cal} .183$ (1869), the court cited common-law jurisdictions, and most of the subsequent cases relied upon Lawrence. See, e.g., McPike v. Heaton, 131 Cal. 109, 63 Pac. 179 (19c0).

101 Even though the remote grantee may need the protection which is not afforded presently by present covenants, there' is some relevance in asking whether the remote grantee deserves such protection. Why shouldn't the remote grantee be required to get express assignments of choses $\mathrm{m}$ action in order to protect himself? Perhaps the most obvious answer is that at the time of the conveyance there is little inkling that something is wrong with the title; otherwise the grantee would not be purchasing. In asking whether the remote grantce deserves protection with present covenants, it may be appropriate to ask another question: Why should the grantor be relieved of his legal obligation by the fortuitous circumstance of a subsequent conveyance?

102 See CaI. Crv. Code $\S 1113$.

${ }^{103}$ See sections III, A \& C supra.

$104 \mathrm{Ibid}$. If the intermediate grantee made express covenants of title in his convcyance to the remote grantee, the remote grantee could sue the intermediate grantee for the acts of the original grantor, as long as the imtermediate grantee's express covenants were not special.

105 See, e.g., Wright v. Boggess, 24 Cal. App. 533, 535-36, 141 Pac. 1082, 1082-83 (1914) (a covenant against encumbrances is a covenant to indemnify the grantees for damages or loss sustained). Covenants that run are true covenants of imdemnity since there is no breach until there is damage. However, even covenants that do not run, such as the covenant against encumbrances, are considered covenants to indemnify since only nominal damages may be recovered until there is an actual loss.

Perhaps it is simplest to say that "mdemnity" has two meanings. With regard to future covenants, "indemnity" means that no cause of action arises until the covenantce has bcen damaged. With regard to present covenants, "indemnity" is used merely to indicate the measure of damages.

10686 Utah 485, 46 P.2d 428 (1935).

107 Soderberg v. Holt, 86 Utah 485, 496-98, 46 P.2d 423, 433 (1935):

In the case of a violation of a covenant against encumbrances, if it is so considercd, the breach really is committed at the time of the conveyance if there is a lien on the 
concerned with the distinction between present and future covenants and evidenced an understandable caution in limiting the holding to certain covenants against encumbrances. However, covenants of title are for the protection of the grantee and the protection should be given to the one who really deserves it-the owner of the land. If the immediate grantee has conveyed to a remote grantee, the immediate grantee no longer has any use for the covenants, unless lie has covenanted with the remote grantee in such a way that he is liable and needs the covenants of the original grantor to protect himself. If the special covenants of California Civil Code section 1113 are the only ones given, the remote grantee has no remedy whatsoever unless he can sue the original grantor, since the special covenants of the intermediate grantee do not cover the acts of the original grantor. ${ }^{108}$

\section{The Solution Advanced by Schofield v. The Iowa Homestead Co.}

The distinction between present and future covenants is deep-seated in the law of covenants, but it is this very distinction that diminishes the value of covenants of title by preventing some of them from running with the land. To abolish the distinction between present and future covenants would require overruling considerable authority and would not necessarily be a good thing. The statute of limitations must begin to run at some time, and when the covenant is broken upon conveyance, the date of the conveyance provides a propitious time for the statute of limitations to begin running. Hence, for statute of limitations purposes, the distinction between present and future covenants is convenient. ${ }^{109}$

premises which the covenantor covenanted was not there. The damage suffered by the buyer because of the necessity to extinguish a charge against the land was a damage suffered because of the failure of the covenantor to convey the property without the said charge, and thus arose from the breach of the covenant, which breach occurred eo instanti at the time of the conveyance. If, on the other hand, the covenant against encumbrances is looked at according to its true content and its truc intention, it should be looked at as a covenant to indemnify. Then no breach occurs until the duty to indemnify is violated, that is, until the buyer pays and demands and the covenantor refuses to respond. Until the buyer pays to extinguish the charge against the land, he cannot ask for indemnity. We believe that this view is most consonant with justice and works in harmoniously with the fabric of those cases where an act occurs which is a violation of a duty and thus starts the statute [of limitations] regardless of when the damage may accrue or be felt; such cases, for instance, as the breach of a contract to insure property against loss by fire, where the statute begins to run at the expiration of a reasonable time within which the policy could be issued and not at the time the fire occurred .... .

We believe that the logical fabric and the law will be beiter maintained and yet justice be done by holding that a covenant against encumbrances is, in effect, a covenant to indermnify where the encumbrance is a charge or lien against the land which can be extinguished by payment. Thus the statute can be held to begin to run only when the grantee is damnified.

108 See hypothetical in text at notes 102-04 supra.

109 In Soderberg v. Holt, 86 Utah 485, 46 P.2d 428 (1935), the court held that some covenants against encumbrances were future and in fact were not broken until there was damage. This seems a desirable distinction, but one which is inapplicable to some covenants, such as a covenant of seisin. If $A$ conveys to $B$, covenanting that he owns the land when in fact he does not, $A$ has broken his promise at the same instant he made it. To say that $B$ 's cause of action would not arise until he learned of $A$ 's breach would mean that $A$ would be subject to suit for an indefimite period, and would eliminate the statute of limitations for all practical purposes. To say that the statute of himitations on a present covenant begins to run from the date of the conveyance does not seem an unduly harsh result; there are many other instances in which the same rule applies. Id. at $497,46 \mathrm{P} .2 \mathrm{~d}$ at 433 . This approach is consistent with the Soderberg result which makes some covenants against encumbrances future. To say that some encumbrances are effective only when there is a real loss is different frcm saying that all present covenants should be future. 
In Schofield v. The Iowa Homestead Co. ${ }^{110}$ the justices of the Supreme Court of Iowa felt that the true purpose of the covenant of seisin was being frustrated by the covenant's inability to run with the land. Clearly, however, the covenant of seisin could not run with the land since it was broken when made arid was no longer a covenant at all but rather a chose in action. The problem was one of permitting the chose in action to pass to the remote grantee. The Iowa court held that the chose in action was assigned by operation of deed.111

This result could be reached in California. Since the purpose of covenants of title is to protect the grantee, they should pass to the grantee in possession of the land. California Civil Code section $954^{112}$ changed the common-law rule ${ }^{113}$ and made choses in action assignable in California. Certainly an express assignment of the chose in action would be valid, and there seems to be no reason preventing the assignment of the chose in action by operation of law. ${ }^{114}$ Holding that choses in action could be assigned by operation of deed would make California Civil Code section 1113 meaningful to the remote grantee.

Assigning the chose in action by operation of deed would not, of course, affect the running of the statute of limitations, and for this reason the distinction between present and future covenants would still be important.

\section{E. The Covenant Against Encumbrances Reconsidered}

California holds that the covenant against encumbrances is a present covenant, ${ }^{115}$ since the encumbrance must have existed at the time of the conveyance. ${ }^{110}$ This loolding places the grantee in a difficult position. The grantee may know of an encumbrance, but must himself pay off the encumbrance before he can collect more than nominal damages. ${ }^{117} \mathrm{By}$ the time the grantee has extinguished the encumbrance, the statute of limitations may bar an action against the grantor on the covenant. Some jurisdictions have solved this problem by dividing encumbrances into two categories, "physical" encumbrances and "money" encumbrances. "Money" encumbrances are then considered future and the statute of limitations runs from the time the grantee extinguishes the encumbrance. As a necessary corollary, so much of the covenant against encumbrances as is considered future then runs with the land.

11032 Iowa 317 (1871).

$111 \mathrm{Id}$. at 320 . In New York, a covenant against encumbrances is assigned by operation of deed. See Clarke v. Priest, 21 App. Div. 174, 47 N.Y. Supp. 489 (1897).

$112 \mathrm{CAL}$. Crv. CODE $\S 954$ reads: " $\mathrm{A}$ thing in action, arising out of the violation of a right of property, or out of an obligation, may be transferred by the owner ...."

113 See Morris v. Standard Oil Co., 200 Cal. 210, 214, 252 Pac. 605, 606 (1926); Dibble v. San Joaquin Light \& Power Corp., 47 Cal. App. 112, 117, 190 Pac. 198, 200 (1920).

114 The use of the words "heirs" and "assigns" in $\S 1113$ would seem to evidence some legislative intent that the statutory covenants pass to the remote grantee. "From the use of the word 'grant' in any conveyance by which an estate of inheritance or fee simple is to be passed, the following covenants, and none other, on the part of the grantor for himself and his heirs to the grantee, his heirs, and assigns, are imphed ...." Cal. CIV. CODE \$1113. (Emphasis added.)

1 I5 McPike v. Heaton, 131 Cal. 109, 63 Pac. 179 (1900); Woodward v. Brown, 119 Cal. 283, 294, 51 Pac. 2, 5, modified per curian, 51 Pac. 542 (1897); Salmon v. Vallejo, 41 Cal. 481 (1871); Lawrence v. Montgomery, 37 Cal. 183, 188-89 (1869); Wright v. Boggess, 24 Cal. App. 533, 535-36, 141 Pac. 1082 (1914).

116 See Wright v. Boggess, 24 Cal. App. 533, 535-36, 141 Pac. 1082 (1914).

117 See CaI. Civ. Code $\$ 3305$. 
Soderberg v. Holt ${ }^{118}$ was a case involving a tax lien. If the cause of action had arisen at the time of the conveyance, the action would have been barred by the statute of limitations. If, however, there was no cause of action until there was a damnification, then the action was good. The court recognized that to hold that the statute of limitations began to run when the plaintiff was damaged would mean that the covent was future and would run with the land. The court resolved this problem by saying that while the covenant against encumbrances was technically broken at the time of the conveyance, it really was not broken until the grantee was damnified; hence, it was future. This was not to be the case for all covenants against encumbrances, however; a covenant against encumbrances would run only when it was, "in effect, a covenant to indemnify where the encumbrance is a charge or lien against the land which can be extinguished by payment."119

In Post v. Campau, ${ }^{120}$ the Michigan Supreme Court said essentially the same thing in stating that there are different kinds of encumbrances, and probably it enunciated the difference more clearly. The court said that a covenant against a right of way assures against something that immediately affects the title and causes present damage, and should not run with the land; however, a covenant against a money charge is breached only technically until the money is due and the cause of action should not arise until the grantee is in fact damaged. The "money covenant" would then be future and would run with the land.

While these cases present an acceptable rationale for achieving a desirable end with some covenants against encumbrances, ${ }^{121}$ they further coinphicate the law of covenants of title by adding further subtleties. The result is to make at least some covenants against encumbrances future, however, and this is laudable because the grantee is given more protection.

\section{CONCLUSION}

About the best that can be said for covenants of title is that they can provide a grantee with protection he doesn't get from the recording acts or from title insurance.

If present covenants could run with the land, covenants of title would be much more useful, particularly to the present day remote grantee taking under a statutory form of grant deed. Both of the covenants implied by section 1113 of the Civil Code are present, both are special, and neither affords the remote grantee any protection against the acts of the original grantor.

Present covenants cannot run with the land, however, for the whole concept of present and future covenants precludes this. Nevertheless, there is no reason why virtually the same result could not be accomplished by holding that covenants of title are assigned by operation of deed. If this were done, the only reason for distingnishing between present and future covenants would be to determine when the statute of limitations begins to run.

In addition, both immediate grantees and remote grantees would benefit from holding certain covenants agamst encumbrances to be future covenants. The stat-

11886 Utah 485, 46 P.2d 428 (1935).

$110 \mathrm{Id}$. at $498,46 \mathrm{P} .2 \mathrm{~d}$ at 433 .

12042 Mich. 90, 3 N.W. 272 (1879) (dictum).

121 Frequently the covenant against encumbrances is classified in the manner suggested, see generally Rawse 91, but not in California. See McPike v. Heaton, 131 Cal. 109, 63 Pac. 179 (1900). 
ute of limitations would not start to run until there was damage, giving the immediate grantee more protection under his covenant. Being future, the covenant would then run with the land and could be sued upon by the remote grantee.

These two changes would effect a beneficial result without basically altering the law of covenants of title. Both changes could be accomplished within the legal framework that now surrounds covenants of title and they would not require any drastic judicial maneuvering to be effectuated.

\section{Charles Evans Goulden}

\section{APPENDIX A \\ THE RECORDING ACTS AND COVENANTS OF TITLE}

The recording acts are one means of protecting a bona fide purchaser of land; covenants of title are another. The protection afforded by each has hittle connection with the other.

The recording acts may determine which innocent purchaser gets the property, but the California recording acts do not change the common law and pernit one who has no estate in land to convey a good estate in land.122 The California recording acts merely protect the first bona fide purchaser for value who records. ${ }^{123}$

The recording acts may give the grantor the power to convey the property again if the grantee fails to record, but this does not mean that the grantor owns the land.124 If a grantor conveys a fee interest, and the grantee fails to record, then the grantor may still be able to convey because the recording acts will protect a bona fide purchaser for value. If the grantor does convey a second time, covenantirig that he owns the land, then he has breached his covenant since he does not own the land.

Since covenants of title are contractual agreements apart and distinct from the recording acts, information of record is important only if the deed provides that the covenants for title do not cover defects of record.

\section{APPENDIX B}

\section{TITLE INSURANCE AS AN ALTERNATIVE TO COVENANTS OF TITLF.}

Title insurance is seen by some as a practical panacea to the problems of conveying real property. 125 Covenants of title are quite old, and it seems legitimate to ask if they are not outmoded, in view of title insurance.

Whatever else may be said, it is safe to state that covenants of title are no longer "in daily use" as they were in $1806 .{ }^{126}$ A recent randoin check of 347 deeds $^{127}$ recorded at the Alaneda County Recorder's Office revealed a possibility of one express covenant of title that appeared in about 20 deeds. ${ }^{128}$ Apparently lawyers feel that covenants of title are not worth inserting,

122 Sec Rose v. Davis, 11 Cal. 133, 134-35 (1858) (a grantor can convey no greater interest than he himself owns).

123 "Every conveyance of real property, other than a lease for a term not exceeding one year, is void as against any subsequent purchaser or mortgagee of the same property, or any part thereof, in good faith and for a valuable consideration, whose conveyance is first duly recorded . . . Cax. Crv. Code \$1214. See generally Beach v. Faust, 2 Cal. 2d 290, 292-93, 40 P.2d 822, 823 (1935); Randall v. Allen, 180 Cal. 298, 299-300, 180 Pac. 941, 942 (1919). 124 See generally IV Asrerican LAw OF Property 527-636 (Casner ed. 1952).

125 This is particularly true of those engaged in the title insurance business. For a proinsurance but essentially imformative discussion of title insurance, see generally Legar Aspects of Rear Estate Transactions ch. 5 (Cahif. Cont. Ed. Bar 1956).

126 See Greenby v. Wilcocks, 2 Johns. R. 1, 5 (N.Y. Sup. Ct. 1806) (dissent of Livingston, J.).

127 The deeds ranged from 1945 to the present, and were selected at five-year intervals.

128 This does not include covenants impled by CAT. CIV. CODE $\$ 1113$. 326 of the 347 deeds used the word "grant" with no qualification so that CAx. CIv. Cope $\$ 1113$ would apply. The clause which might be a covenant of non-claim and thus a covenant of warranty is as follows:

Together with all and singular the tenements, hereditaments, and appurtenances thereunto belonging or in anywise appertaining, and the reversion and reversions, re- 
or else most people use forms supplied by title companies and these forms do not include covenants of title other than the covenants implied by California Civil Code section 1113.129 It is also possible, of course, that grantors object to giving covenants, but as long as they have dore nothing to impeach the title they should bave no objection. The most reasonable explanation for the dearth of express covenants is that grantees are relying upon the statutory covenants ${ }^{130}$ or upon title insurance for protection.

The California Land Title Association Standard Coverage Policy Fornu (1960) excludes practically everything that is not of record. ${ }^{131}$ Additional coverage car be had if the insured

mainder and remainders, rents, issues, and profits thereof. And also all the estate, right, title, interest, possession, claim and demand whatsoever, as well in law as in equity, of the said parties of the first part [the grantors], of, in, or to the above described premises and every part or parcel thereof, with the appurtenances. (Emphasis added.)

More likely than not, however, the clause quoted above is not an express covenant. Probably the parties to such an instrument would not have the requisite intent to be bound. Compare the clause ahove with the following, which was held to be a covenant of non-claim:

To have and to hold the above granted premises and the privileges and appurtenances thereto belonging so that neither I . . . [the grantor] nor my heirs, or any person or persons, claiming from or under me shall have, claim, or demand, any right or title to the aforesaid premises, or any part or parcel thereof.

Gee v. Moore, 14 Cal. 472, 473 (1859). The court noted in Gee that even though the usual words of a covenant were wanting, the words used "clearly indicate an engagement of the grantor that neither he, nor his heirs, nor any parties under or through him, will ever assert any right to the estate conveyed." Ibid.

129 See note 30 supra.

130 The statutory covenants give the remote grantee no protection against acts of the original grantor simce the immediate grantee is covenanting only that be bimself bas not previously conveyed or encumbered the property; the statutory covenants are special covenants. See section III, A \& C supra.

\section{EXCLUSIONS FROM THE COVERAGE OF THIS POLICY}

This policy does not insure against loss or damage by reason of the following:

(a) Any law, ordinance or governmental regulation (including but not limited to building and zoning ordinances) restricting, regulating or prohibiting the occupancy, use or enjoyment of the land, or the character, dimensions or location of any improvement now or hereafter erected on said land, or prohibiting a reduction in the dimensions, area or separation in ownership, of any lot or parcel of land.

(b) Governmental right of police power or eminent domain unless notice of judicial action to exercise such rights appears in the public records at the date hereof.

(c) Title to any property beyond the lines of the premises expressly described in Schedule A, or title to streets, roads, avenues, lanes or ways on which such premises abut, or the right to maintain therein vaults, tunnels, ramps or any other structure or improvement, or any rights or easements therein unless this policy specifically provides that such property, rights or easements are insured, except that if the premises abut upon a physically open street or highway this policy insures the ordinary rights of abutting owners for access thereto unless restricted by governmental regulations or otherwise excepted or excluded herem.

(d) Defects, hens, encumbrances, adverse claims against the title as insured or other matters (1) created, suffered, assumed or agreed to by the Insured, or (2) known to the Insured either at the date of this policy or at the date such Insured acquired an estate or interest insured by the policy and not shown by the public records, unless disclosure thereof in writing hy the Insured shall have been made to the Companies prior to the date of this policy, or (3) resulting in no direct loss to the Insured, or (4) attaching or created subsequent to the date hereof.

(e) Loss or damage which would not have been sustained if the Insured were a bona fide purchaser or encumbrancer for value.

SCHEDULE B

This policy does not insure against loss or damage by reason of matters shown in Parts One and Two hereof: 
is willing to pay for it, ${ }^{132}$ but the need for additional coverage appears to be something that would not be discovered until it was too late. Inserting covenants of title in the deed would supplement title insurance, but would not replace it. The title insurance company is more likely to remain solvent than any particular grantor, but at least covenants of title would provide some protection in those areas not covered by the insurance policy.

\section{PART ONE:}

1. Taxes or assessments which are not shown as existing liens by the records of any taxing authority that levies taxes or assessments on real property or by the public records.

2. Any facts, rights, interests, or claims which are not shown by the public records but wbich could be ascertained by an inspection of said land or by making inquiry of persons in possession thereof.

3. Easements, claims of easement or encumbrances which are not shown by the public records.

4. Discrepancies, confiicts in boundary lines, shortage in area, encroachments or any other facts which a correct survey would disclose.

5. Unpatented mining claims; reservations or exceptions in patents or in Acts authorizing the issuance thereof; water rights, claims or title to water ....

132 "Additional coverage" includes insurance against what, essentially, could be learned by a casual physieal inspection of the premises.

Some idea of the expense of title insurance can be obtained from a perusal of the short excerpt taken from the rate schedule of the North American Title Insurance Company of Oakland, California, which follows (prices apply only to Alameda, Contra Costa, and Sacramento counties):

Standard Rate

$\$ 40.00$

72.00

109.00

164.00

214.00
"Additional Coverage"

Add to Standard Rate

$\$ 18.00$

18.00

21.80

32.80

42.80 